\title{
Deleterious PALB2 Gene Mutation
}

National Cancer Institute

\section{Source}

National Cancer Institute. Deleterious PALB2 Gene Mutation. NCI Thesaurus. Code C131775.

A change in the nucleotide sequence of the PALB2 gene that is associated with increased risk of disease. 